\title{
Lysine and zinc chelate in diets for brown laying hens: effects on egg production and composition ${ }^{1}$
}

\author{
Messias Alves da Trindade Neto ${ }^{2}$, Bruna Helena Carvalho Pacheco ${ }^{3}$, Ricardo de \\ Albuquerque $^{2}$, Eliana Aparecida Schammass ${ }^{4}$
}

\author{
1 Projeto financiado pela Fundação de Apoio à Pesquisa do Estado de Sao Paulo - FAPESP, Brasil. \\ 2 Departmento de Produção e Nutrição Animal da FMVZ-USP, Brasil. \\ 3 Programa de pós-graduação do Departamento de Produção e Nutrição Animal da FMVZ-USP, Brasil. \\ ${ }^{4}$ Instituto de Zootecnia - Rua Heitor Penteado 56, Nova Odessa - SP, Brasil.
}

ABSTRACT - It was evaluated the effects of levels of digestible lysine and chelate zinc combined in the diet for laying on the egg quality. It was used 720 birds, from 48 to 60 weeks of age, distributed in a completely randomized design in a $3 \times 5$ factorial scheme with three levels of zinc and five levels of lysine, applied into six replicates in the experimental units of eight birds per plot. The levels were: 137, 309 and 655 ppm zinc and 0.482, 0.527, 0.582, 0.644 and 0.732\% digestible lysine. It was not observed any interaction among digestible lysine and zinc for the primary variables of fractions and egg composition. Levels of zinc reduced egg weight, suggesting the lowest efficiency in nutrient intake. At the highest dietary concentration of zinc, the addition of digestible lysine coincided with a linear increase in shell weight. However, zinc addition, regardless of lysine level in the diet, resulted in the reduction of egg weight and of the percentage of mineral matter in the yolk, limiting the efficiency of mineral deposition in this fraction of the egg. Concentration of zinc that produced the best results was $137 \mathrm{ppm}$ inasmuch as higher quantities limit the use of digestible lysine, with effects harming composition and egg quality. The study indicates the following requirement for digestible lysine: $0.639 \%$ from the $48^{\text {th }}$ to the $52^{\text {nd }}$ week, $0.679 \%$ from the $52^{\text {nd }}$ to $56^{\text {th }}$ week, and $0.635 \%$ from the $56^{\text {th }}$ to the $60^{\text {th }}$ week. Considering the total period from $48^{\text {th }}$ to the $60^{\text {th }}$ week, the level $0.638 \%$ of lysine or the daily intake of $707 \mathrm{mg}$ of the amino acid met the requirement for egg quality of semiheavy layers used in this study.

Key Words: digestible amino acid, lipid and protein deposition

\section{Lisina e zinco quelato em dietas de poedeiras marrons: efeitos na produção e composição dos ovos}

\begin{abstract}
RESUMO - Avaliaram-se os efeitos dos níveis lisina digestível e zinco quelato combinados na dieta de galinhas poedeiras sobre a qualidade do ovo. Foram usadas 720 aves de 48 a 60 semanas de idade, distribuídas em delineamento inteiramente casualizado em arranjo fatorial $3 \times 5$ com três níveis de zinco e cinco níveis de lisina aplicados a seis repetições em unidades experimentais de oito aves por parcela. Os níveis foram: 137, 309 e 655 ppm de zinco e 0,482; 0,527; 0,582; 0,644; 0,732\% de lisina digestível. Não se constatou interação de lisina digestível e zinco para as principais variáveis das frações e composição do ovo. O nível de zinco reduziu o peso do ovo e isso sugere menor eficiência na absorção de nutrientes. Na maior concentração dietética de zinco, o acréscimo de lisina digestível coincidiu com aumento linear no peso da casca. Por outro lado, o acréscimo de zinco, independentemente do nível de lisina na dieta, culminou na redução do peso do ovo e da porcentagem da matéria mineral na gema limitando a eficiência de deposição mineral nessa fração do ovo. A concentração de zinco que promoveu os melhores resultados foi a de $137 \mathrm{ppm}$, uma vez que quantidades mais elevadas limitaram o uso de lisina digestível, com efeitos prejudiciais à composição e qualidade do ovo. As exigências de lisina digestível foram de 0,639\% da 48a à 52aㅡ semana; 0,679\%

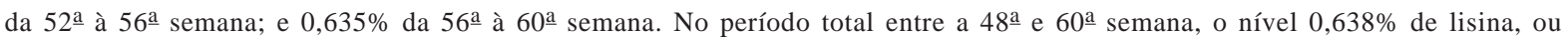
a ingestão diária de $707 \mathrm{mg}$ desse aminoácido, atende às necessidades para qualidade de ovo de galinhas poedeiras semipesadas.
\end{abstract}

Palavras-chave: aminoácido digestível, deposição lipídica e proteica

\section{Introduction}

The knowledge of protein and mineral requirements for lying hens in production is of fundamental importance inasmuch as the intake of protein, particularly amino acids, influence the production and egg size (NRC, 1994). Because of the increase in egg production of hens present, gradual changes in the demands for amino acids occurred. 
In this case, lysine, considered as the standard amino acid in relation to other amino acids, is the nutrient primarily associated with egg mass protein (Novak et al., 2004; Gunawardana et al., 2008). So, when prioritized in protein synthesis, the correct use of lysine and other amino acids in the diets of birds allows more efficient use of nutrients (Namazu et al., 2008).

Although the production of chelated minerals in Brazil started during the 1970s, research on their use in animal nutrition is limited (Mabe, 2001; Hudson et al., 2004, 2005; Namazu et al., 2008). Their importance has been discussed based on specific actions in the preintestinal absorption and after absorption in cellular metabolism due to higher bioavailability when compared with the same minerals in inorganic form. Due to a higher bioavailability, chelated minerals can be used in small quantity in the diet thereby producing beneficial effects on the animal while minimizing environmental pollution (Hudson et al., 2004, 2005).

Zinc, which is a trace mineral, is essential to the metabolism of proteins, carbohydrates, fat and is associated with multiple enzymatic activities in the body. In addition to cell division, DNA synthesis and protein, zinc is associated with tissue growth, immune functions, prostaglandin production and bone mineralization (Cheng et al., 1998). Compared to inorganic form, in organic form, zinc is more available for animal(Aoyagi \& Baker, 1993), becoming an option on mineral nutrition, as well as in egg production.

The objective of this study was to evaluate the effect of dietary concentrations of lysine and zinc chelate (above the recommended) on production and composition of brown egg laying hens in the period 48-60 weeks of age.

\section{Material and Methods}

The study was conducted in the experimental aviary, Departamento de Nutrição e Produção Animal of FMVZ, Universidade de São Paulo, Pirassununga, SP, Brazil.

In a randomized experimental design, 720 commercial brown laying hens from 48 to 60 weeks of age were distributed. During 12 weeks of evaluation, three controls (52, 56 and 60 weeks of age) of production variables were performed. Data for chemical composition of albumen, yolk and whole egg without the shell were obtained at the end of the trial period. The treatments were applied in a the $3 \times 5$ factorial arrangement, the first factor ppm zinc and the second level percentage of lysine, applied in six replicates. The experimental unit was composed of eight birds per cage.
The birds were distributed in pairs, cages twin built in galvanized wire, measuring $0.25 \times 0.40 \times 0.40 \mathrm{~m}$, arranged in line. All hens were supplied with feed and water ad libitum. Animal housing and handling procedures during experimentation were approved by Comissão de Ética of FMVZ-USP.

The experimental diets, according to laboratory analysis, had 137, 309 and $655 \mathrm{ppm}$ of zinc chelate and the lysine levels were formulated to meet $0.50 ; 0.60 ; 0.70 ; 0.80$ and $1.00 \%$. The diets were based on corn and soybean meal. Other nutritional requirements were met as recommended by Rostagno et al. (2005). Lysine and other amino acids were added in order to meet the relationships established as the most suitable for laying hens.

The $\mathrm{Zn}$ value (35 ppm) was obtained from ingredients corn, soybean meal, gluten meal $60 \%$ and limestone. The levels of the amino acid analyzed by Ajinomoto, according to the method described in AOAC Official Method 994.12, Amino Acids in Feeds Performic Acid Hydrolysis-Acid Oxidation with Sodium Metabisulfite Method (1984) were $0.560,0.612,0.677,0.748$, and $0.851 \%$ of lysine. Digestible lysine values were corrected for digestibility weight index (0.8605 or $86.05 \%)$, according to the inclusion of each ingredient in the diet, following information in Tabelas Brasileiras para Aves e Suínos (Rostagno et al., 2005). The corrected values were $0.482,0.527,0.582,0.644$ and $0.732 \%$ of digestible amino acid. Estimates of lysine level from the regression equations were also adjusted to the levels determined by laboratory analysis.

Analyses of ingredients and diets (Table 1) were conducted in the Laboratory Bromatology of Department of Nutrition and Animal Production, according to the procedures described by AOAC (1984).

The characteristics of egg quality were evaluated at the end of each experimental control (28 days) using three eggs for each plot, except for density which was assessed for all the eggs in the plot. Eggs were identified according to the experimental diet and weighed individually by using a scale with 0.01-g accuracy. Weights were obtained from the yolk, albumen and egg shell.

The specific gravity was measured in a solution of distilled water and salt in six different densities from 1.070 to 1.100 at intervals of 0.005 measured with a densimeter, according to the technique mentioned by Hamilton (1982). Eggs from each plot were one- by-one dipped into the solutions to determine the corresponding densities.

Haugh unit was obtained by the relationship between egg weight (g) and albumen height ( $\mathrm{mm}$ ) using the formula described by Ferreira et al. (1996) in which: $\mathrm{UH}=100 \mathrm{log}$ (A - 1.7 $\left.\mathrm{P}^{0.37}+7.6\right), \mathrm{A}=$ albumen height $(\mathrm{mm})$ and $\mathrm{P}=$ egg 
Table 1 - Ingredient composition and calculated nutrient analysis of the diets provided to commercial brown laying hens from 48 to 60 weeks of age, according to formulated lysine level

\begin{tabular}{|c|c|c|c|c|c|}
\hline & \multicolumn{5}{|c|}{ Digestible lysine $^{1}$} \\
\hline Grounded corn & 72.391 & 71.708 & 69.737 & 67.719 & 66.237 \\
\hline Wheat bran & 1.594 & 0.090 & - & - & - \\
\hline Soybean oil & - & - & 0.247 & 0.501 & 0.570 \\
\hline L-Lysine $\mathrm{HCl}$ & - & 0.067 & 0.148 & 0.232 & 0.465 \\
\hline L-Tryptophan & - & 0.013 & 0.028 & 0.044 & 0.087 \\
\hline Salt & 0.500 & 0.500 & 0.500 & 0.500 & 0.500 \\
\hline Limestone & 8.885 & 8.873 & 8.869 & 8.864 & 8.861 \\
\hline Dicalcium phosphate & 1.262 & 1.261 & 1.251 & 1.242 & 1.238 \\
\hline Choline chloride & 0.050 & 0.050 & 0.050 & 0.050 & 0.050 \\
\hline Other (Zinc carbochelate/sand) & 1.143 & 1.143 & 1.143 & 1.143 & 1.143 \\
\hline Metabolizable energy $(\mathrm{kcal} / \mathrm{kg})^{6}$ & 2800 & 2800 & 2800 & 2800 & 2800 \\
\hline Protein $(\%)^{5}$ & 13.860 & 13.090 & 14.220 & 14.340 & 13.600 \\
\hline Calcium $(\%)^{6}$ & 3.800 & 3.800 & 3.800 & 3.800 & 3.800 \\
\hline Available phosphorus $(\%)^{6}$ & 0.326 & 0.326 & 0.326 & 0.326 & 0.326 \\
\hline Sodium $(\%)^{6}$ & 0.224 & 0.224 & 0.224 & 0.223 & 0.223 \\
\hline Digestible methionine + cystine $(\%)^{6}$ & 0.541 & 0.546 & 0.637 & 0.728 & 0.910 \\
\hline Digestible threonine $(\%)^{6}$ & 0.504 & 0.433 & 0.462 & 0.528 & 0.660 \\
\hline Tryptophan $(\%)^{6}$ & 0.116 & 0.138 & 0.161 & 0.184 & 0.230 \\
\hline Digestible leucine $(\%)^{6}$ & 1.161 & 1.213 & 1.244 & 1.272 & 1.283 \\
\hline Digestible arginine $(\%)^{6}$ & 0.693 & 0.746 & 0.790 & 0.831 & 0.853 \\
\hline Digestible isoleucine $(\%)^{6}$ & 0.475 & 0.510 & 0.536 & 0.560 & 0.572 \\
\hline Digestible valine $(\%)^{6}$ & 0.547 & 0.580 & 0.604 & 0.627 & 0.637 \\
\hline
\end{tabular}

weight (g). The albumen height was measured by using an altimeter.

Evaluation of chemical composition of the eggs was performed at the end of the experimental phase. Each sample was composed of three yolks and albumens were weighed separately, then homogenized and packed in containers with lids. The samples were lyophilized and analyzed following the procedures described by AOAC (1984). Samples were analyzed for crude protein, ether extract, ash and water in natural matter and lyophilized matter, then corrected to $100 \%$ dry matter.

Statistical analysis of the egg quality and composition variables was performed using the Statistical Analysis System computer program - (SAS, 2004). When assessing the effect of zinc concentration, polynomial regression was considered significant only for linear response because only three levels were used; however, Tukey test was used to validate or not the answers which were characterized as linear or quadratic responses.

\section{Results and Discussion}

There was no interaction between zinc and lysine levels on egg production. However, each factor had effect on egg production. With respect to the use of zinc (Table 2 and 3), the increased concentration of mineral coincided with a linear decrease $(\mathrm{P}=$ throughout the experimental period $(P=0.007)$. The reduction in egg weight due to increased dietary zinc suggests a lower efficiency of nutrient absorption, as pointed out by Hudson et al. (2005) on the performance of chickens from 0 to 17 days of age. This adverse effect was suggested by Park et al. (2004), in a review of the zinc role on poultry nutrition, indicating that the excess of this mineral has a negative effect on feed intake and egg production, causing lesions in the pancreas and gizzard of laying hens.

For shell weight, considering the entire period of evaluation, from 48 to 60 weeks of age, there was an interaction $(\mathrm{P}=0.03)$ among factors. Moreover, the addition of lysine in 
Table 2 - Egg composition of laying hens at the end of 60 weeks of age, according to the levels of dietary zinc and lysine

\begin{tabular}{|c|c|c|c|c|c|c|c|c|c|c|c|c|}
\hline \multirow{2}{*}{$\begin{array}{l}\text { Variable } \\
\text { Data of natural matter }\end{array}$} & \multicolumn{3}{|c|}{ Zinc (ppm) } & \multicolumn{5}{|c|}{ Digestible lysine $(\%)^{1}$} & \multirow[t]{2}{*}{ CV (\%) } & \multicolumn{3}{|c|}{ Significance } \\
\hline & 137 & 309 & 655 & 0.482 & 0.527 & 0.582 & 0.644 & 0.732 & & Zinc & Lysine & Zinc $\times$ Lysin \\
\hline Egg weight (g) & 64.4 & 64.5 & 62.9 & 62.0 & 63.2 & 65.0 & 64.7 & 64.9 & 4.59 & ns & 0.01 & ns \\
\hline Egg weight without shell (g) & 54.2 & 54.3 & 53.2 & 52.2 & 53.6 & 54.9 & 54.2 & 54.9 & 5.01 & ns & 0.03 & ns \\
\hline Shell weight (g) & $6.7 \mathrm{a}$ & $6.6 b$ & $6.5 b$ & 6.5 & 6.6 & 6.7 & 6.7 & 6.7 & 5.44 & ns & 0.07 & 0.05 \\
\hline Albumen weight (g) & 37.7 & 37.5 & 37.0 & 37.0 & 37.7 & 32.2 & 36.9 & 37.1 & 6.43 & ns & ns & ns \\
\hline Yolk weight (g) & 16.5 & 16.5 & 16.2 & 15.2 & 16.0 & 16.7 & 17.3 & 16.9 & 7.0 & ns & 0.00003 & ns \\
\hline Egg water content (\%) & 77.67 & 776.7 & 77.61 & 78.14 & 77.85 & 77.73 & 77.34 & 77.17 & 0.89 & ns & 0.0007 & ns \\
\hline Egg protein content (\%) & 11.01 & 10.99 & 11.02 & 11.14 & 11.16 & 10.81 & 10.87 & 11.05 & 2.62 & ns & 0.0009 & ns \\
\hline Egg ether extract content (\%) & 10.06 & 10.22 & 10.23 & 9.50 & 9.74 & 10.28 & 10.69 & 10.65 & 5.03 & ns & 0.00001 & ns \\
\hline Egg ash content (\%) & $1.25 \mathrm{a}$ & $1.11 \mathrm{~b}$ & $1.13 \mathrm{~b}$ & 1.21 & 1.23 & 1.15 & 1.09 & 1.12 & 12.30 & ns & 0.02 & 0.002 \\
\hline
\end{tabular}

${ }^{1}$ Estimated values from digestibility factor 0.8605 , obtained as an average weight of ingredients used in formulation of diets and corrected by total amino acids analyzed of diets.

Different letters show effect by Tukey test $(\mathrm{P}<0.05)$; CV\% = coefficient of variation; ns = no significant effect.

Table 3 - Regression equations for lysine levels and chelate zinc concentrations in the experimental controls performed for laying hens from 48 to 60 weeks of age

\begin{tabular}{|c|c|c|c|}
\hline Variable/week intervals & Lysine & Probability & $\begin{array}{c}\text { Coefficient of } \\
\text { determination }\left(\mathrm{R}^{2}\right), \%\end{array}$ \\
\hline Egg weight (56-60 weeks of age) & $Y=47.79+39.654879 X-22.62112 X^{2}$ & 0.05 & 93.98 \\
\hline Egg weight without shell (56-60 weeks of age) & $Y=39.83+35.58240 X-21.08942 X^{2}$ & 0.03 & 84.75 \\
\hline Yolk weight (56-60 weeks of age) & $Y=5.63+26.68007 X-15.390607 X^{2}$ & 0.001 & 98.22 \\
\hline Egg weight (48-60 weeks of age) & $Y=51.81+27.86702 X-15.98062 X^{2}$ & 0.02 & 99.80 \\
\hline Egg weight (48-52 weeks of age) & $Y=16.20+19.34850 X-12.18499 X^{2}$ & 0.02 & 65.03 \\
\hline Egg weight (52-56 weeks of age) & $Y=17.13+13.24087 X-7.13303 X^{2}$ & 0.07 & 98.84 \\
\hline Egg weight (56-60 weeks of age) & $Y=5.65+26.60244 X-15.33873 X^{2}$ & 0.001 & 98.39 \\
\hline Egg water content (48-60 weeks of age) & $\mathrm{Y}=79.0652-1.96172 \mathrm{X}$ & 0.00009 & 93.88 \\
\hline Egg protein content (48-60 weeks of age) & $Y=3.31-6.18269 X+3.91430 X^{2}$ & 0.001 & 67.11. \\
\hline \multirow[t]{2}{*}{ Egg ether extract content (48-60 weeks of age) } & $Y=4.94+12.11240 X-6.36565 X^{2}$ & 0.002 & 94.69 \\
\hline & Zinc & & \\
\hline Egg weight (48-52 weeks of age) & $Y=63.18-0.021238 X$ & 0.07 & 92.93 \\
\hline Egg weight (56-60 weeks of age) & $Y=65.22-0.027298 X$ & 0.03 & 87.73 \\
\hline Egg weight (48-60 weeks of age) & $Y=64.07-0.020464 X$ & 0.007 & 97.05 \\
\hline Shell weight (48-60 weeks of age) & $Y=6.68-0.003429 X$ & 0.001 & 91.09 \\
\hline
\end{tabular}

diets with 655 ppm of zinc coincided with a linear $(P=0.001)$ increase of shell weight (Table 2). Hudson et al. (2004), when using chickens at 58 weeks of age also observed a better quality of eggshell when the birds were submitted to mineral levels above the required, but the reverse occurred at 66 weeks of age. This response in the shell weight, however, was better characterized by the effect caused by increasing concentrations of the amino acid, when it increased the egg weight during the evaluation periods. As reported by Yamaguchi et al. (1988) and Cheng et al. (1998), protein synthesis related to zinc is restricted to bone tissue and in the present study, probably to the egg shell. In this case, the increase on weight of the whole egg depends on the increase of lysine in the diet, as observed by Martinez et al. (2005) referring to the current layer hen in its bigger production.

Considering the factor lysine (Table 2), it is observed that increasing dietary amino acid suggests a linear increase ( $P=0.07$ ) on shell weight (Table 2 ) when birds are at 60 weeks of age. This response showed a quadratic increase in the egg weight without the shell $(\mathrm{P}=0.02)$ when dietary lysine was added in the same period and in the remaining time interval (48-52, 53-56 and 57-60 weeks), including total period (Table 3 ).

The estimated level of amino acid, adjusted proportionately for the laboratory analysis would be $0.638 \%$ for the total period. It could be observed that for the relative value (percentage) of shell weight the treatment effects were not apparent. Thus, lysine affected the increase in egg weight and this increase was proportional to the shell. Prochaska \& Carey (1993), Scheideler et al. (1996), Novak et al. (2004) and Liu et al. (2005) also found no difference in the percentage of shell eggs in birds fed different amounts of dietary lysine. Ratifying therefore, the observations of Yamagushi et al (1988) and Cheng et al. (1998) restated that protein synthesis is not related to zinc, except for the bone tissue.

For the use of zinc, it was observed that increase in the concentration of this mineral coincided with a reduction $(\mathrm{P}=0.002)$ in shell weight in controls performed in the week 52 and week $60(P=0.10)$. In a study on breeding birds for 
broiler production, Hudson et al. (2004) found that dietary zinc in high concentration reduced shell thickness of eggs of hens at 66 weeks of age. Considering the forced molting, Park et al. (2004) also observed that at high dietary concentrations, zinc can reduce the use of calcium by the hen, because this element would be the first limiting factor for ovulation.

For egg fractions (Table 2), there were no interactions between lysine and zinc, but it was characterized a quadratic effect of lysine factor on yolk weight, which did not occur in the albumen. Digestible amino acids levels estimated as optimal were $0.581 \%$ at the end of week $52(\mathrm{P}=0.02), 0.679 \%$ at the end of the week $56(\mathrm{P}=0.07)$ and $0.635 \%$ at the end of the week $60(\mathrm{P}=0.001)$ of age of the bird. The variation of estimated levels coincided with the increase in egg weight which varied from 60.7 to $62.4 \mathrm{~g}$ at the end of the first control, 62.4 to $63.3 \mathrm{~g}$ at the end of the second control and 62 to $64.7 \mathrm{~g}$ at the end of the third experimental control, in response to changes in the lysine level. The same occurred with shell weight, which varied $(\mathrm{P}=0.002)$ from 6.3 to 6.7 , when it was considered throughout the assessment period (48 to 60 weeks of age).

Also, when total period was considered, there was a quadratic response $(\mathrm{P}=0.0004)$ for factor lysine on egg yolk weight. In this case, the estimated level of lysine was $0.638 \%$ for the consumption of $110.8 \mathrm{~g} / \mathrm{bird} /$ day and daily intake of 707 mg of lysine which is a level lower than those recommended by NRC (1994) and by Rostagno et al. (2005), suggesting $0.76 \%$ and $0.70 \%$ of digestible amino acid, respectively.

The results of this study confirm those obtained by Prochaska et al. (1996), who found greater weight of the yolk when hens received higher levels of dietary lysine. However, they go against Liu et al. (2005) and Sá et al. (2007), who observed no effect of lysine levels in egg yolk weight. In contrast, Novak et al. (2004) observed lower weight of yolk, when laying hens were fed greater levels of lysine in the diet.

On chemical composition of the egg (Table 2) in natural matter, at the end of the trial period, there was an isolated effect of lysine (Table 3 ) in the percentages of water $(\mathrm{P}=0.00009)$, protein $(\mathrm{P}=0.001)$ and ether extract $(\mathrm{P}=0.002)$. It was observed that under increasing concentration of lysine, protein was reduced to a certain point, and the reverse occurred in the composition of lipids. Based on egg protein content, the lower concentration would be under the level $0.635 \%$ of lysine and higher concentration of lipids would be under $0.639 \%$ of lysine, corrected according to amino acids analysis and digestibility indices. The levels of lysine indicated for both variables are close to $0.638 \%$, estimated for egg weight in the total period. Considering the importance of lysine for protein synthesis, the egg protein content would be more appropriate as a benchmark when comparing these variables, however, the corresponding coefficient of determination of equation (67.11) does not ensure accuracy for its estimate.

After removing the water from the egg fractions (Table 4) by the lyophilization method, there was no significant effect from lysine and zinc on dry matter or water content of the albumen. For yolk dry matter, there was a quadratic effect $(\mathrm{P}=0.02)$ when lysine was increased in the diet. The smallest amount of dry matter occurred in $0.613 \%$ of

Table 4 - Composition of egg fractions in laying hens at the end of 60 weeks of age, according to the levels of zinc and lysine ${ }^{1}$

\begin{tabular}{|c|c|c|c|c|c|c|c|c|c|c|c|c|}
\hline \multirow{2}{*}{$\begin{array}{l}\text { Variable } \\
\text { Data of natural matter }\end{array}$} & \multicolumn{3}{|c|}{ Zinc (ppm) } & \multicolumn{5}{|c|}{ Digestible lysine $(\%)^{1}$} & \multirow[t]{2}{*}{ CV (\%) } & \multicolumn{3}{|c|}{ Significance } \\
\hline & 137 & 309 & 655 & 0.482 & 0.527 & 0.582 & 0.644 & 0.732 & & Zinc & Lysine & Zinc $\times$ Lysine \\
\hline Albumen protein (\%) & 8.55 & 8.52 & 8.54 & 8.38 & 8.46 & 8.44 & 8.57 & 8.83 & 3.96 & ns & 0.02 & ns \\
\hline Yolk protein (\%) & 16.65 & 16.67 & 16.70 & 17.87 & 17.51 & 16.25 & 15.79 & 15.94 & 3.16 & ns & 0.00001 & ns \\
\hline Albumen ether extract (\%) & 1.63 & 1.63 & 1.55 & 1.67 & 1.71 & 1.66 & 1.63 & 1.34 & 10.52 & ns & 0.00001 & ns \\
\hline Yolk ether extract (\%) & 29.3 & 30.0 & 30.0 & 28.6 & 28.7 & 30.0 & 30.0 & 31.4 & 3.75 & 0.01 & 0.00001 & ns \\
\hline Albumen ash (\%) & 0.62 & 0.64 & 0.66 & 0.65 & 0.63 & 0.64 & 0.62 & 0.65 & 10.02 & ns & ns & ns \\
\hline Yolk ash (\%) & $2.70 \mathrm{a}$ & 2.19b & $1.18 \mathrm{~b}$ & 2.60 & 2.65 & 2.32 & 2.09 & 2.15 & 20.18 & ns & 0.001 & 0.003 \\
\hline \multicolumn{13}{|l|}{ Freeze-dried data } \\
\hline Albumen dry matter (\%) & 10.81 & 10.80 & 10.76 & 10.69 & 10.81 & 10.75 & 10.85 & 10.84 & 3.94 & ns & ns & ns \\
\hline Albumen protein $(\%)^{1}$ & 79.13 & 79.05 & 79.34 & 78.36 & 78.29 & 78.52 & 79.01 & 81.70 & 1.4 & ns & 0.00001 & ns \\
\hline Albumen ether extract $(\%)^{1}$ & 15.11 & 15.03 & 14.49 & 15.56 & 15.82 & 15.58 & 15.24 & 12.29 & 8.59 & ns & 0.00001 & ns \\
\hline Albumen ash $(\%)^{1}$ & 5.74 & 5.90 & 6.14 & 6.05 & 5.89 & 6.00 & 5.71 & 6.00 & 10.24 & 0.03 & ns & ns \\
\hline Yolk dry matter (\%) & 48.62 & 48.86 & 49.00 & 49.02 & 48.91 & 48.63 & 47.93 & 49.59 & 3.03 & ns & 0.02 & ns \\
\hline Yolk protein $(\%)^{1}$ & 34.26 & 34.06 & 34.13 & 36.45 & 35.77 & 33.43 & 32.91 & 32.20 & 0.86 & 0.035 & 0.00001 & ns \\
\hline Yolk ether extract $(\%)^{1}$ & $60.20 \mathrm{~b}$ & $61.35 a$ & $61.35 a$ & 58.86 & 58.77 & 61.79 & 62.66 & 63.36 & 1.74 & ns & 0.00001 & 0.0002 \\
\hline Yolk ash $(\%)^{1}$ & 5.53a & $4.52 b$ & $4.49 \mathrm{~b}$ & 5.29 & 5.42 & 4.77 & 4.38 & 4.36 & 20.33 & 0.003 & ns & 0.005 \\
\hline
\end{tabular}

${ }^{1}$ Estimated values from digestibility factor 0.8605 , obtained as an average weight of ingredients used in formulation of diets and corrected by total amino acids analyzed of diets.

Letter differ by Tuckey test $(\mathrm{P}<0.05)$.

$\mathrm{CV} \%=$ coefficient of variation; ns = not significant effect. 
digestible lysine, coinciding with the reduction of protein and lipids increased in that same fraction.

On composition of dry yolk, there was an interaction $(\mathrm{P}=0.00001)$ of the studied factors, however, the most pronounced effect resulted from variation of dietary lysine (Table 4). The responses of zinc within the factor lysine were characterized by frequent inconsistency of results, predominantly quadratic responses. In this case, the interactions with quadratic effects of zinc were not considered to have evaluated only three levels of the mineral, so the coefficient of determination for quadratic responses indicated $100 \%$ accuracy, which is not real, according to the results obtained. Furthermore, increased levels of the amino acid at all concentrations of zinc have coincided with the linear reduction of $11 \%$ in the protein concentration. At the same time, increased dietary amino acid at all concentrations of zinc coincided with $7 \%$ increase in ether extract of the yolk. As observed by Namazu et al. (2008), the lower intake of zinc, the lower lipid deposition in broilers, when varying the concentration of the 43-253 ppm in the diet. In the same studies, it was shown that for the highest dietary concentration, organic zinc causes a greater utilization of energy intake, with effects on lipid deposition.

Based on the yolk protein concentration, responses differ from the ones reported by Prochaska \& Carey (1996), who observed an increase of this component in the same fraction of the egg. Similarly, Novak et al. (2004) did not obtain differences in yolk protein by increasing the concentration of the same amino acid in the diet. However, the current result agrees with Novak et al. (2006), who observed an inverse relationship when reduced the amino acid in the diet, and reported increasing of protein content, according to reduction of dietary lysine concentration.
It was also observed in mineral composition of freezedried egg yolk, an interaction between lysine and zinc in the ash content. The increase of amino acid coincided with a linear reduction of ash at all levels of zinc. Likewise, there was a pronounced effect of increased zinc concentration in the linear decrease $(\mathrm{P}=0.003)$ of the ash in yolk. From the highest to the lowest level of mineral inclusion, ash was reduced by $19 \%$. This same relative difference was observed in varying levels of lysine which, probably, is related to increased level of lipids in the yolk.

In freeze-dried albumen fraction, the result was opposite to the yolk. The increase of dietary lysine resulted in a linear increase of $4 \%$ protein and $21 \%$ linear reduction of the ether extract. This response confirms that lysine metabolism is directed to protein synthesis, with the deposition of water, as featured in the albumen fraction and the reduced fat deposition would be the result of increased efficiency. The daily intake of lysine determines the intensity of protein synthesis by certain concentrations, but insufficient energy intake to achieve this process would limit the use of amino acid. For factor zinc, it was found a positive linear response $(\mathrm{P}=0.001)$ in percentage of ash in albumen.

The density and Haugh unit were not significantly different in all experimental controls, which is in agreement with Novak et al. (2004), Jordan Son et al. (2006) and Sá et al. (2007).

On daily rates of nutrient deposition in the egg without the shell and its fractions (Table 5), there were no interaction of lysine and zinc for the accumulation of water, protein and lipids. Amino acid and mineral interaction was characterized on mineral fraction of yolk $(\mathrm{P}=0.01)$ and total ash $(\mathrm{P}=0.03)$. At concentrations of 137 and 309 ppm zinc, digestible lysine quadratically responded $(\mathrm{P}<0.05)$ for the mineral deposition

Table 5 - Deposition of chemical components in fractions of yolk, albumen and whole egg of laying hens at the end of 60 weeks of age, according to the levels of zinc and lysine in the diet

\begin{tabular}{|c|c|c|c|c|c|c|c|c|c|c|c|c|}
\hline \multirow[t]{2}{*}{ Variable g/day } & \multicolumn{3}{|c|}{ Zinc (ppm) } & \multicolumn{5}{|c|}{ Digestible lysine $(\%)^{1}$} & \multirow[t]{2}{*}{$\mathrm{CV}(\%)$} & \multicolumn{3}{|c|}{ Significance } \\
\hline & 137 & 309 & 655 & 0.482 & 0.527 & 0.582 & 0.644 & 0.732 & & Zinc & Lysine & Zinc $\times$ Lysine \\
\hline Albumen water & 33.6 & 33.4 & 33.0 & 33.0 & 33.6 & 34.0 & 32.9 & 33.1 & 6.41 & ns & ns & ns \\
\hline Yolk water & 8.5 & 8.3 & 8.3 & 7.7 & 8.2 & 8.6 & 9.0 & 8.3 & 9.38 & ns & 0.0003 & ns \\
\hline Total water ${ }^{2}$ & 42.1 & 42.1 & 41.3 & 40.8 & 41.7 & 42.7 & 41.9 & 42.0 & 5.31 & ns & ns & ns \\
\hline Albumen protein & 3.26 & 3.20 & 3.16 & 3.10 & 3.19 & 3.23 & 3.22 & 3.29 & 7.29 & ns & 0.02 & ns \\
\hline Yolk protein & 2.74 & 2.74 & 2.70 & 2.71 & 2.79 & 2.71 & 2.72 & 2.69 & 6.04 & ns & ns & ns \\
\hline Total protein ${ }^{2}$ & 5.97 & 5.97 & 5.84 & 5.81 & 5.95 & 5.94 & 5.89 & 6.03 & 5.32 & ns & ns & ns \\
\hline Albumen ether extract & 0.62 & 0.60 & 0.58 & 0.61 & 0.64 & 0.64 & 0.61 & 0.50 & 12.19 & ns & 0.00001 & ns \\
\hline Yolk ether extract & 4.83 & 4.93 & 4.87 & 4.34 & 4.59 & 4.98 & 5.18 & 5.31 & 6.7 & ns & 0.00001 & ns \\
\hline Total ether extract ${ }^{2}$ & 5.45 & 5.55 & 5.45 & 4.93 & 5.24 & 5.64 & 5.79 & 5.82 & 6.17 & ns & 0.00001 & ns \\
\hline Albumen ash & 0.23 & 0.24 & 0.24 & 0.24 & 0.24 & 0.24 & 0.23 & 0.24 & 12.73 & ns & ns & ns \\
\hline Yolk ash & 0.45 & 0.36 & 0.35 & 0.39 & 0.42 & 0.39 & 0.36 & 0.36 & 20.55 & ns & ns & 0.01 \\
\hline Total ash ${ }^{2}$ & 0.68 & 0.59 & 0.60 & 0.63 & 0.66 & 0.63 & 0.59 & 0.60 & 13.70 & ns & ns & 0.03 \\
\hline Egg total deposition ${ }^{2}$ & 54.20 & 54.28 & 54.19 & 52.20 & 53.66 & 54.94 & 54.21 & 54.44 & 5.01 & ns & 0.03 & ns \\
\hline
\end{tabular}

${ }^{1}$ Estimated values from digestibility index 0.8605 , obtained as an average weight of ingredients used in formulation of diets and corrected by total dietary amino acids, $\mathrm{CV} \%=$ coefficient of variation; ns = no significant effect.

2 Egg without shell. 
Table 6 - Regression equations of lysine effect on deposition of chemical components (g/day)

\begin{tabular}{|c|c|c|c|}
\hline & Lysine & Probability & $\begin{array}{c}\text { Coefficient of } \\
\text { determination }\left(\mathrm{R}^{2}\right), \%\end{array}$ \\
\hline Egg weight (56-60 weeks of age) & $Y=47.79+39.654879 X-22.62112 X^{2}$ & 0.05 & 93.98 \\
\hline Yolk water & $Y=0.82158+19.83441 X-12.29059 X^{2}$ & 0.0003 & 82.17 \\
\hline Yolk ether extract & $\mathrm{Y}=1.23785+8.16840 \mathrm{X}-4.08513 \mathrm{X}^{2}$ & 0.002 & 98.57 \\
\hline Albumen ether extract & $\mathrm{Y}=0.09535+1.65868 \mathrm{X}-1.25859 \mathrm{X}^{2}$ & 0.0001 & 99.32 \\
\hline Total ether extract & $Y=1.22459+10.12383 X-5.52630 X^{2}$ & 0.0002 & 98.66 \\
\hline Total ash at $137 \mathrm{ppm}$ of zinc & $\mathrm{Y}=0.00214+1.81588 \mathrm{X}-1.14703 \mathrm{X}^{2}$ & 0.05 & 75.01 \\
\hline Total ash at $309 \mathrm{ppm}$ of zinc & $Y=0.79090-0.27162 X$ & 0.04 & 68.78 \\
\hline Egg total deposition without shell & $Y=39.8283+35.58245 X-21.08942 X^{2}$ & 0.04 & 84.75 \\
\hline
\end{tabular}

of the yolk with estimated values of the amino acid of $0.571 \%$ and $0.647 \%$, respectively. The greatest demand for the amino acid at the highest concentration of dietary zinc coincides with the observation by Hudson et al. (2005), in which nutrient absorption is less efficient when the concentration of the mineral is high. The greatest apparent need of lysine, due to the increase in the concentration of zinc, does not correspond to greater efficiency in the use of amino acid by the bird.

When it is considered the variation of lysine factor in daily rates of deposition (Tables 5 and 6), there was a quadratic response $(\mathrm{P}=0.0003)$ of the amino acid in yolk water indicating the same effect $(\mathrm{P}=0.07)$ in total water of egg without the shell, estimating the amino acid at $0.649 \%$ according to analyzed results from diet and digestibility index. Such responses coincide with increased protein concentration of albumen, confirming the relationship of protein synthesis in the deposition of water in tissue formation (Trindade Neto et al., 2004).

Albumen protein $(\mathrm{P}=0.02)$ and ether extract of yolk $(P=0.002)$ increased linearly in response to increasing dietary lysine (Table 6). The deposition of lipids in the albumen ( $P=0.00001)$ and total lipids $(P=0.0002)$ were quadratic for increasing dietary lysine. Based on total lipids, the estimated level of digestible amino acid would be $0.670 \%$, however, this variable would not be the best option for determining this requirement, considering the relationship between protein deposition and water in the tissues.

There was an interaction of lysine and zinc in mineral deposition of yolk $(\mathrm{P}<0.01)$ and mineral total deposition ( $P=0.03$ ) of egg (Table 6). At the 309 ppm concentration of zinc, the variation of dietary lysine produced significant effect $(\mathrm{P}<0.05)$ according to the quadratic equation $\mathrm{Y}=1.13-1.87916 \mathrm{X}+1.06235 \mathrm{X}^{2}, \mathrm{R}^{2}=99.47$. The lowest yolk mineral deposition occurs at the estimated level of $0.647 \%$ of the amino acid. From the lowest level of lysine to the level estimated as optimal, deposition was reduced by 33\%, confirming that excess of zinc does not help the metabolic efficiency of amino acid. Increasing zinc in the diet resulted in a reduction of $21 \%$ in mineral deposition. As noted by Park et al. (2004) and Hudson et al. (2005), in excess, zinc has detrimental effect on egg production, affecting the absorption of nutrients, and causing lesions in the pancreas and gizzard of laying hens. The greatest apparent need of lysine, under high concentration of zinc in the diet, does not correspond to increased efficiency in the use of amino acid by the bird, and then the absorption is probably affected, as shown by the data on production and egg composition.

\section{Conclusions}

In organic form, the better concentration of zinc chelate is 137 ppm whereas greater quantities of zinc limits the use of lysine and negatively affect yield and composition of eggs. In the period from 48 to 60 weeks of age, the level 0.638 digestible lysine, corresponding to daily intake of $707 \mathrm{mg}$ of amino acid, meets the requirements for egg quality of semi-heavy laying hens.

\section{References}

AOYAGI, S.; BAKER, D.H. Nutritional evaluation of a cooperlysine and zinc-lysine complexes for chicks. Poultry Science, v.72, n.1, p.16-171, 1993.

ASSOCIATION ON OFFICIAL ANALYTICAL CHEMISTS AOAC. Official methods of analysis. 14.ed. Arlington: Association of Official Analytical Chemists, 1984. 1141p.

CHENG, J.; KORNEGAY, E.T.; SCHELL, T. Influence of dietary lysine on the utilization of zinc from zinc sulfate and a zinclysine complex by young pigs. Journal of Animal Science, v.76, p.1064-1074, 1998.

CHEN, M.D.; LIN, P.Y.; CHENG, V.; LIN, W.H. Zinc Supplementation aggravates body fat accumulation in genetically obese mice and dietary-obese mice. Biological Trace Element Research, v.52, p.125-132, 1996.

FERREIRA, S.W.; COLNAGO, L.A.; MELO, S. et al. Recomendação sobre o uso do medidor de altura de 
albúmen de ovos. Concórdia: Embrapa Suínos e Aves, 1996. p.1-5. (Comunicado Técnico, 13).

GUNAWARDANA， P.; ROLAND， D.A; BRYANT, M.M. Performance comparison and lysine requirements of seven commercial brown egg layer strains during phase one. International Journal Poultry Science, v.7, p.806-812, 2008.

HAMILTON, R.M.G. Methods and factors that affect the measurement of egg shell quality. Poultry Science, v.61, n.6, p.2022-2039, 1982.

HUDSON, B.P.; DOZIER,W.A.; WILSON, J.L. et al. Reproductive performance and immune status of caged broiler breeder hens provided diets supplemented with either inorganic or organic sources of zinc from hatching to $65 \mathrm{wk}$ af age. Journal Applied of Poultry Research, v.13, p.349-359, 2004.

HUDSON, B.P.; DOZIER III, W.A.; WILSON, J.L. Broiler live performance response to dietary zinc source and the influence of zinc supplementation in broiler breeder diets. Animal Feed Science and Technology, v.118, n.3-4, p.329-335, 2005.

JORDÃO FILHO, J.; SILVA, J.H.V.; SILVA, E.L. et al. Exigência de lisina para poedeiras semipesadas durante o pico de postura. Revista Brasileira de Zootecnia, v.35, n.4, p.1728-1734, 2006 (supl.).

LIU, Z.; WU, G.; BRYANT, M.M. et al. Influence of added synthetic lysine in low-protein diets with the methionine plus cysteine to lysine ratio maintained at 0,75. Journal Applied of Poultry Research, v.14, n.2, p.174-182, 2005.

MABE, I. Efeitos da suplementação dietética com quelatos de zinco e de manganês na produção de ovos e morfologia intestinal de galinhas poedeiras. 2001. 94f. Tese (Doutorado) - Faculdade de Ciências Farmacêuticas da Universidade de São Paulo, São Paulo.

MARTÍNEZ, B.F.; CRUZ, A.D.; LÓPEZ, J.L. et al. Necesidades de lisina y aminoácidos azufrados digestibles in gallinas Legorn Blancas. Veterinaria México, v.36, n.2, p.135-145, 2005.

NATIONAL RESEARCH COUNCIL - NRC. Nutrient requirements of poultry. 9.ed. Washington, D.C.: National Academic Press, 1994. 155p.

NAMAZU, L.B.; KOBASHIGAWA, E.; ALBUQUERQUE, R. et al. Lisina digestível e Zn quelado para frangos de corte machos: desempenho e retenção de nitrogênio na fase pré-inicial. Revista Brasileira de Zootecnia, v.37, n.9, p.1634-1640, 2008

NOVAK, C.L.; YAKOUT, H.S.; SCHEIDELER, S. The combined effects of dietary lysine and total sulfur amino acid level on egg production parameters and egg components in dekalb delta laying hens. Poultry Science, v.83, p.977-984, 2004.
NOVAK, C.; YAKOUT, H.S.; SCHEIDELER, S.E. The effect of dietary protein level and total sulfur amino acid: lysine ratio on egg production parameters and egg yield in Hy-line W-98 hens. Poultry Science, v.85, p.2195-2206, 2006.

PARK, S.Y., BIRKHOLD, S.G., KUBENA, L.F. et al. Review on the role of dietary zinc in poultry nutrition, immunity, and reproduction. Biological Trace Element Research, v.102, n.2, p.147-163, 2004.

PROCHASKA, J.F.; CAREY, J.B. Influence of dietary lysine on egg production and liquid egg composition. Poultry Science, v.72, n.10, p.186, 1993. Supplement 1. (Abstract).

PROCHASKA, J.F.; CAREY, J.B.; SHAFER, D.J. The effect of L-Lysine intake on egg composition in laying hens. Poultry Science, v.75, n.10, p.1268-1277, 1996.

ROSTAGNO, H.S.; ALBINO, L.F.T.; DONZELE, J.L. et al. Composição de alimentos e exigências nutricionais de aves e suínos (Tabelas brasileiras para aves e suínos). Viçosa, MG: UFV/Departamento de Zootecnia, 2005. 186p.

SÁ, L.M.; GOMES, P.C.; ROSTAGNO, H.S.; ALBINO, L.F.T et al. Exigência nutricional de lisina digestível para galinhas poedeiras no período de 34 a 50 semanas de idade. Revista Brasileira de Zootecnia, v.36, p.1829-1836, 2007.

SCHEIDELER, S.E.; NOVAK, C.; SELL, J.L. et al. Hisex White Leghorn lysine requirement for optium body weight and egg production during early lay. Poultry Science, v.75, p.86, 1996. Supplement 1, (Abstracts).

STATISTICAL ANALYSES SYSTEM - SAS. User's guide: statistic. 12.ed. New York: SCOTT, M.L. \& Associates, 2004. 1686p.

TALLMAN, D.L.; TAYLOR, C.G. Effects of dietary fat and zinc on adiposity, serum leptin and adipose fatty acid composition in C57BL/6J mice. The Journal of Nutritional Biochemistry, v.14, n.1, p.17-23, 2003.

TRINDADE NETO, M.A.; PETELINCAR, I.M.; BERTO, D.A. et al. Níveis de lisina para leitões na fase inicial-1 do crescimento pósdesmame: composição corporal aos 11,9 e $19,0 \mathrm{~kg}$. Revista Brasileira de Zootecnia, v.33, n.6, p.1777-1789, 2004 (supl. 1).

YAMAGUSHI, M.; OISHI, H.; SUKETA, Y. Zinc stimulation of bone protein synthesis in tissue culture. Activation of aminoacyl-tRNA synthetase. Biochemistry and Pharmacology, v.37, n.21, p.4075-80, 1988.

ZONTA, E. P.; MACHADO, A. A.; SILVA JUNIOR, P. Sistema de análise estatística - SANEST, Registro na SEI no. 066060. Pelotas: [s.n.], 1982. 